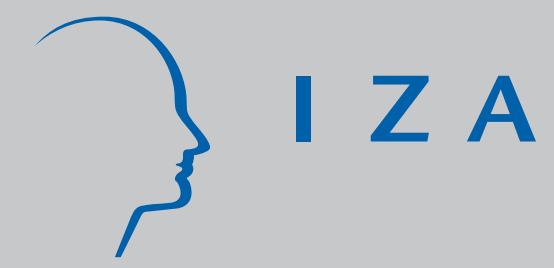

IZA DP No. 228

The College Wage Gap in 10 European

Countries: Evidence from Two Cohorts

Giorgio Brunello

Simona Comi

Claudio Lucifora

December 2000 


\title{
The College Wage Gap in 10 European Countries: Evidence from Two Cohorts
}

\author{
Giorgio Brunello \\ University of Padova, CESifo, Munich and IZA, Bonn
}

Simona Comi

Fondazione ENI Enrico Mattei, Milan

Claudio Lucifora

Catholic University of Milan

Discussion Paper No. 228

December 2000

\author{
IZA \\ P.O. Box 7240 \\ D-53072 Bonn \\ Germany \\ Tel.: +49-228-3894-0 \\ Fax: +49-228-3894-210 \\ Email: iza@iza.org
}

This Discussion Paper is issued within the framework of IZA's research area The Future of Work. Any opinions expressed here are those of the author(s) and not those of the institute. Research disseminated by IZA may include views on policy, but the institute itself takes no institutional policy positions.

The Institute for the Study of Labor (IZA) in Bonn is a local and virtual international research center and a place of communication between science, politics and business. IZA is an independent, nonprofit limited liability company (Gesellschaft mit beschränkter Haftung) supported by the Deutsche Post AG. The center is associated with the University of Bonn and offers a stimulating research environment through its research networks, research support, and visitors and doctoral programs. IZA engages in (i) original and internationally competitive research in all fields of labor economics, (ii) development of policy concepts, and (iii) dissemination of research results and concepts to the interested public. The current research program deals with (1) mobility and flexibility of labor markets, (2) internationalization of labor markets and European integration, (3) the welfare state and labor markets, (4) labor markets in transition, (5) the future of work, (6) project evaluation and (7) general labor economics.

IZA Discussion Papers often represent preliminary work and are circulated to encourage discussion. Citation of such a paper should account for its provisional character. 
IZA Discussion Paper No. 228

December 2000

\section{ABSTRACT \\ The College Wage Gap in 10 European Countries: Evidence from Two Cohorts*}

We study the recent evolution of the college wage gap with a unique data set that comprises two cohorts and 10 European countries from the early to mid 1980s to the mid to late 1990s. We find evidence of significant cross country differences in the level and dynamics of the gap. There is also evidence that both the level and the growth of the college wage gap significantly differ between cohorts. The estimated growth in the gap turns out to be negatively correlated to changes in relative supply and positively correlated both with the long run rate of productivity growth and with an index of between industry demand shocks. Institutional changes also matter, and we find that countries that have experienced declines in union density, in the centralization of the wage bargain and in employment protection measures have also had a faster growth in the college wage gap.

JEL Classification: J31

Keywords: Education, earnings, Europe

Giorgio Brunello

Department of Economics

University of Padova

Via del Santo 33

I - 35100 Padua

Tel.: $+39(0) 49827-4223$

Fax : +39 (0) 49 827-4211/4221

Email: brunello@vi.nettuno.it

\footnotetext{
* This paper is part of the PURE research project funded by the European Community. We are grateful to the project partners for providing the data, to the audience at the PURE workshop in Lisbon for comments and to Eli Berman for detailed suggestions. Part of the work leading to this draft was completed while the first author was visiting Essex University (ECASS) and Boston University. The usual disclaimer applies.
} 


\section{Introduction}

The wage structures of several OECD countries experienced, over the last decades, significant changes. Overall wage inequality and wage differentials across different groups of workers showed a marked departure with respect to the trends which had characterized earlier periods. In this respect, various factors, both of economic and institutional source, contributed to re-shaping the distribution of wages. Major changes occurred in the distribution of the labor force by educational level and by labor market skills, partly driven by the educational choices of the "baby boom" generation and partly due to the changing structure of employment following the diffusion of computer technologies.

Two leading explanations have been offered to account for the observed changes in relative wages: one story has emphasized the role of market forces and the evolution of (relative) supply and demand; another story has stressed the role of labor market imperfections and institutional arrangements. The former approach focuses mainly on demographic changes, adverse shifts in supply and demand for products, skill-biased technological change, and the increased globalization of trade (OECD, 1996; Gottschalk and Smeeding, 1997; Berman et al. (1994); Acemoglu (2000)). The latter approach advocates the importance of trade unions, of collective bargaining practices and of product and labor market regulations (Blau and Kahn, 1996; Fortin and Lemieux, 1997; DiNardo, et al., 1996).

Changes have had different impact on younger and older cohorts. Card and Lemieux (2000), for instance, use data on workers of different age groups to show that in the US much of the rise in the college-high school wage gap can be attributed to changes in the relative earnings of younger college-educated workers. They also show that this shift in the structure of returns to college graduates shares a common pattern in the UK and Canada, where educational wage differentials have risen for younger men while remaining stable or even declining for older men.

While there is an extensive literature investigating the evolution of the col- 
lege wage gap in the North American and British experiences ( see for instance Bound and Johnson, 1992; Katz and Autor, 1999), relatively little is known about the (continental) European experience. We believe that a better understanding of the European case is interesting not only in itself, but also because the countries involved show a relatively high degree of variation in the evolution of relative prices and quantities for different skills and exhibit significant institutional diversity.

In this paper we use data for two cohorts of males to study the recent evolution of the college wage gap in 10 European countries and highlight both common trends and country specific differences. We focus on cohort data for two reasons, to disentangle composition effects from genuine changes in relative wages; and to ask whether the patterns in the dynamics of the college wage gap uncovered for the US and other Anglo-Saxon countries apply also to the rest of Europe.

This study uses a unique data set that comprises two cohorts and 10 European countries from the early to mid 1980s to the mid to late 1990s. We believe that our contribution to the existing literature is twofold: first, and most obviously, we offer a broad European perspective to the recent evolution of the college wage gap; second, we exploit the rich institutional variation of European labor markets to correlate the levels and trends in the college wage gap with the levels and changes in European labor market institutions.

To preview our results, we find evidence of significant cross country differences in the level and growth of the college wage gap. There is also evidence that both the level and the growth of the college wage gap significantly differ between cohorts. Estimated growth turns out to be negatively correlated to changes in relative supply and positively correlated both to an index of between industries demand shocks and to the long run rate of labor productivity growth. The latter finding is consistent with different demand side explanations, including skill biased technical change and capital - skill complementarity. Institutional changes also matter, and we find that countries that have experienced a decline in union density, in the centralization of the wage bargain and in employment 
protection measures have also had a faster growth in the college wage gap.

The paper is organized as follows. Section 2 introduces the theoretical framework. The next section describes the data and provides an overview of the main facts. Section 4 contrasts aggregate and cohort specific college wage gaps and Section 5 presents and estimates a simple statistical model. In the last section, we correlate the level and the evolution of cohort specific college wage gaps to the levels and changes in relative supply, relative demand and institutional constraints. Conclusions follow.

\section{A Theoretical Framework}

Following the conceptual approach suggested by Bound and Johnson (1992), we model relative wage dynamics as the combination of competitive market forces and non - competitive factors arising from market imperfections as well as institutional arrangements (Katz and Autor, 1999; Card and Lemieux, 2000). In this context, observed $(\log )$ wages $(W)$ can be decomposed into a 'latent' competitive (log) wage level $\left(W_{e}\right)$ and an additional non - competitive $(\log )$ rent $(M)$ that accounts for any deviation of the actual wage from the market clearing wage ${ }^{1}$. The wage of group $j$ can be specified as the sum of the competitive wage and rents

$$
W_{j}=W_{e, j}+M_{j}
$$

Whilst the competitive wage can be thought of as arising from the interaction of relative supply and demand, rents originate from different sources, including non - competitive and institutional factors. Using the above decomposition, the cohort and country specific college - high school wage gap can be written as follows (in logs)

\footnotetext{
${ }^{1}$ Measurement problems related to unobservable nonpecuniary aspects of the job reward structure can also contribute to deviations of observed wages from their competitive level.
} 


$$
r_{c j t}=\frac{W_{\text {ejuct }}}{W_{\text {ejsct }}}+\frac{M_{\text {juct }}}{M_{\text {jsct }}}
$$

where the subscript $u$ is for college, $s$ is for (upper) secondary school, $t$ is for time, $c$ is for the country and $j$ is for the birth cohort. Since earnings grow with individual age, we can re - write the competitive wage gap as

$$
\frac{W_{\text {ejuct }}}{W_{\text {ejsct }}}=\frac{W_{\text {ejuc0 }}}{W_{\text {ejsc0 } 0}} \frac{e^{\gamma_{c j} A_{j u c t}}}{e^{\delta_{c j} A_{j s c t}}}
$$

where $A$ is individual age and the subscript 0 refers to the market wage net of age effects. Since $A_{j u c t} \simeq A_{j s c t}$, age can be decomposed as

$$
A_{j u c t}=A_{j s c t}=A_{j c 0}+t
$$

where $t$ is a linear time trend, $A_{j c 0}$ is age at the beginning of the sample period for cohort $j$, and we can write the competitive wage as

$$
\frac{W_{e j u c t}}{W_{e j s c t}}=\frac{W_{e j u c 0}}{W_{e j s c 0}} e^{\left(\gamma_{c j}-\delta_{c j}\right)\left(A_{j c 0}+t\right)}
$$

Similarly, we can decompose non competitive rents into a time invariant and a time variant component as follows

$$
\frac{M_{j u c t}}{M_{j s c t}}=\frac{M_{j u c 0}}{M_{j s c 0}} e^{\lambda_{c j} t}
$$

We next restrict attention to two cohorts and define aggregate high school and college labor as follows

$$
\begin{aligned}
& S_{c t}=\left[\alpha_{1 c} S_{1 c t}^{\eta}+\alpha_{2 c} S_{2 c t}^{\eta}\right]^{\frac{1}{\eta}} \\
& U_{c t}=\left[\beta_{1 c} U_{1 c t}^{\eta}+\beta_{2 c} U_{2 c t}^{\eta}\right]^{\frac{1}{\eta}}
\end{aligned}
$$

where $S_{1}, S_{2}, U_{1}$ and $U_{2}$ are high school and college labor for the older and the younger cohort and $\alpha_{j c}$ and $\beta_{j c}$ are relative efficiency parameters. Next, assume a CES production function

$$
Y_{c t}=\left[\theta_{s c t} S_{c t}^{\sigma}+\theta_{u c t} U_{c t}^{\sigma}\right]^{\frac{1}{\sigma}}
$$


where $\theta$ are education - specific technical shift parameters.

Using the fact that the competitive wage is equal to the value of the marginal product, the college wage gap for each cohort can be written as

$$
\begin{aligned}
r_{c j t}= & \ln \frac{\theta_{u c t}}{\theta_{s c t}}+(\sigma-\eta) \ln \frac{U_{c t}}{S_{c t}}+\ln \frac{\alpha_{j c}}{\beta_{j c}}+\left(\gamma_{c j}-\delta_{c j}\right)\left(A_{j c 0}+t\right) \\
& +(\eta-1) \ln \frac{H_{j c t}}{S_{j c t}}+\frac{M_{j u c 0}}{M_{j s c 0}}+\lambda_{c j} t
\end{aligned}
$$

Since we consider only the sample period that follows the completion of full time education, the relative supply of college and high school graduates in each cohort is roughly constant over time. Hence, the above expression can be written as

$$
\begin{aligned}
r_{c j t}= & {\left[\ln \frac{\alpha_{j c}}{\beta_{j c}}+(\eta-1) \ln \frac{H_{j c}}{S_{j c}}+\left(\gamma_{c j}-\delta_{c j}\right) A_{j c 0}+\frac{M_{j u c 0}}{M_{j s c 0}}\right] } \\
& +\left[\ln \frac{\theta_{u c t}}{\theta_{s c t}}+(\sigma-\eta) \ln \frac{U_{c t}}{S_{c t}}+\left(\gamma_{c j}-\delta_{c j}+\lambda_{c j}\right) t\right]
\end{aligned}
$$

The first element on the right hand side varies only by country and cohort and is a time invariant country specific cohort effect. The second element varies by country, cohort and over time. Therefore the model implies that the evolution of the college wage gap in each country can be decomposed into time effects, cohort effects and interactions between time and cohort effects. Time invariant effects include cohort - specific relative supply and efficiency parameters, age at the beginning of the sample period and institutional effects affecting non - competitive relative premia. Time variant effects include aggregate relative supply and technical shifts, differences in earnings profiles and changing non competitive rents.

Our primary interest in the rest of the paper is to assess whether both country and cohort effects play a significant role in determining the level and the evolution of the college wage gap in European countries and to evaluate the role played by institutions vis-à-vis market forces in the observed patterns 
of educational wage differentials. Before turning to the estimates, the following section describes the data and presents an overview of the relevant stylized facts for the ten European countries considered in this study.

\section{The College Wage Gap: an Overview}

Comparative work on educational attainment and returns is generally based on the ISCED definitions implemented by the OECD, that try to standardize and rank different educational levels into primary, secondary and tertiary education. While this standardization is not without problems (see Manning and Manacorda, 2000; Freeman and Schettkat, 2000), it has been widely used in the literature and represents a useful benchmark for work in the area. Our data set is structured in the form of a pseudo panel - by educational levels and cohorts - obtained from national microdata (cross sections of individuals). For each country, the mapping from school attainment to the ISCED classification follows the OECD guidelines and does not very over time.

We use average (hourly) wages of full time male employees (part timers are included only in France, but they are few) by educational attainment (compulsory, upper secondary and tertiary) for 10 European countries over the period ranging from the early to mid 1980s to the mid to late 1990s, depending on the country. The definition of educational attainment follows the ISCED classification: compulsory education spans ISCED levels 1 and 2, upper secondary education corresponds to ISCED levels 3 and 4 and tertiary education refers to ISCED levels higher than 4.

On the basis of the above classification, we use two alternative definitions of the educational wage gap: the "college - high school" wage gap in the main text and the "college - less than college" wage gap in the Appendix. The former definition, that is widely used in the North American literature as a proxy for the skilled - unskilled wage gap, excludes individuals with only compulsory education, who are an important fraction of the labor force, especially in Southern Europe. These individuals are typically unskilled and are included in the second 
definition of the gap, that we introduce as a complement to our main results. In both cases we define the gap as the log of the ratio of average (hourly) wages 2 .

The countries included in this study are Austria, Denmark, Finland, France, (West) Germany, Italy, The Netherlands, Portugal, Switzerland and the UK. Further details on data sources are provided in the Data Appendix.

In Figure 1 we use data from all cohorts to plot the average college - high school wage gap for each country, at the beginning and at the end of the available sample period ${ }^{3}$. For most countries, we take the mid 1980s as the starting date and the mid to late 1990s as the ending date ${ }^{4}$. We smooth short term variations by using (weighted) averages of two consecutive years. If the wage gap by education did not change significantly over the period, countries would be distributed along the $45^{\circ}$ line: those with larger gaps positioned in the upperright corner, and those with smaller gaps to the lower - left corner. Deviations from the solid line suggest changes in the gaps.

Contrary to the general perception of a widespread significant increase of college wage gaps, the evidence suggests the presence of significant heterogeneity across European countries. In some countries, the college wage gap has increased over the period (Denmark, Portugal, UK, Italy, Switzerland and Finland), while in other countries it has remained relatively stable (France, Germany and The Netherlands) or even declined (Austria).

The patterns presented so far can prove to be overly restrictive when significant differences across age groups exist. In particular, by interacting with successive labor market cohorts, both market and institutional forces can contribute to alter the wage distribution not only by skill but also across different age groups within each skill group. These issues are addressed in the following section.

\footnotetext{
${ }^{2}$ Wages are gross of taxes in all countries with the exception of Austria and Italy.

${ }^{3}$ Figure A1 in the Appendix presents similar evidence for the college - less than college gap.

${ }^{4}$ Because of data availability, the starting date is 1990 for France and 1992 for Switzerland.
} 


\section{Aggregate and cohort-specific wage gaps}

The overview presented above maintains that in order to study the college wage gap it is sufficient to look at average college and high school (hourly) wages, thus implicitly assuming that workers belonging to different age groups are perfectly substitutable in production, that economic shocks are likely to have the same impact on different cohorts and, finally, that no significant changes in the composition and quality of successive cohorts can occur. In other words, wage differentials for different age groups should rise and fall proportionally over time with a structure that is, in principle, fully accounted by age and year effects.

When relative wages vary among different cohorts of workers, however, the evolution over time of the average college wage gap depends both on the dynamics of cohort - specific relative wages and on the changing composition of employment by cohort. For instance, the average college wage gap could be increasing over time either because the relative wage paid to college workers is increasing across cohorts or because the younger cohort experiences a higher wage gap than the older cohort. Over time, the older cohort is naturally phased out and the younger cohort moves in. In this case, the higher wage gap enjoyed by the latter cohort is sufficient to generate an increasing wage gap even though the gap itself does not vary over time. We try to disentangle composition effects from changes in relative wages by using cohort data, and by focusing on the evolution over time of the college wage gap for particular cohorts.

For each country, we select two cohorts, one that comprises individuals born between 1940 and 1949 and the other comprising those born between 1950 and 1959. We choose ten years ranges in order to have a reasonable number of observations in each cohort. Individuals born before 1940 are excluded, both because they went to school either before or during the Second World War and because their numbers decline rapidly in national surveys during the 1980s and 1990s. For each cohort, we group individuals by level of educational attainment (upper 
secondary and tertiary education). With data by cohort and educational level, we need to minimize within-cohort transitions from one educational attainment to another because of school completion. In order to do so, we both exclude individuals born after 1959 and limit our observation of the younger cohort to the years after 1985, when most individuals in the cohort had presumably completed college education ${ }^{5}$.

Table 1 and Figures 2 and 3 compare for each selected cohort the college wage gap at the beginning and at the end of the sample period and highlight the heterogeneity in the behavior of the gap across cohorts and countries. In Austria and in the Netherlands, for instance, the college wage gap was lower at the end than at the start of the sample period for the older cohort and higher for the younger cohort.

Table 1. College/ high school wage gap. Males only. Cohort specific and aggregate changes.

\begin{tabular}{l|ccc|ccc|c|c}
\hline \hline & Born & $40-$ & 49 & Born & $50-$ & 59 & All cohorts & Years \\
\hline & $80 \mathrm{~s}$ & $90 \mathrm{~s}$ & $\Delta$ & $80 \mathrm{~s}$ & $90 \mathrm{~s}$ & $\Delta$ & $\Delta$ & \\
\hline Austria & .547 & .501 & -8.4 & .321 & .371 & 15.6 & -12.3 & $85-97$ \\
Denmark & .177 & .274 & 54.8 & .141 & .275 & 95.0 & 43.5 & $85-95$ \\
Finland & .382 & .443 & 15.9 & .365 & .379 & 3.8 & 3.7 & $87-93$ \\
France & .316 & .330 & 4.4 & .349 & .353 & 1.1 & -0.3 & $90-98$ \\
Germany & .401 & .477 & 18.9 & .378 & .413 & 9.2 & -1.9 & $85-97$ \\
Italy & .192 & .319 & 66.1 & .245 & .277 & 13.0 & 26.5 & $87-98$ \\
Netherlands & .270 & .180 & -33.3 & .164 & .191 & 16.4 & 2.6 & $86-96$ \\
Portugal & .178 & .398 & 123.6 & .464 & .569 & 22.6 & 63.2 & $85-93$ \\
Switzerland & .334 & .352 & 5.4 & .283 & .324 & 14.5 & 10.6 & $92-98$ \\
UK & .267 & .275 & 3.0 & .203 & .305 & 50.2 & 23.3 & $85-95$ \\
\hline \hline
\end{tabular}

Notes. 80s: initial value; 90s: final value; $\Delta$ :\% change. Years: sample period used for both cohort specific and aggregate variations in the gap.

Interestingly, the increase in the college wage gap between the end and the start of the sample period has been higher for the younger generation in half of the countries in our sample (Austria, Denmark, The Netherlands, Switzerland and the UK) and higher for the older generation in the rest of the sample (Finland, France, Germany, Italy and Portugal). When we consider the college

\footnotetext{
${ }^{5}$ The exclusion of individuals born after 1959 is a major difference with respect to the work of Card and Lemieux (2000). The older cohort is followed for the entire available sample period, that is specified in the Data Appendix.
} 
- less than college wage gap, we also find interesting variation across cohorts and between cohort - specific data and aggregate data, that broadly confirm the findings in Table $1^{6}$.

\section{$5 \quad$ A statistical model of the college wage gap}

Equation (11) suggests that the evolution of the college wage gap can be accounted for by a combination of time invariant cohort by country specific effects and of time effects that vary by cohort and country. Using a linear trend to capture time effects and pooling the available cohort data, we adopt the following empirical specification

$r_{c t}=\sum_{c} \alpha_{c} D_{c}+\beta C+\sum_{c} \gamma_{c} C * D_{c}+\delta t+\sum_{c} \zeta_{c} D_{c} * t+\sum_{c} \theta_{c} C * D_{c} * t+\varepsilon_{c t}$

where $D_{c}$ are country dummies, $C$ is a cohort dummy, equal to 1 for individuals born between 1950 and 1959 and to 0 otherwise, $t$ is a linear time trend, $\varepsilon$ is the error term and we allow for two sets of interactions, one involving time and country dummies and the other involving time, cohort and country dummies. Whilst the former set captures differences in the linear trend across countries, the latter set picks up further differences between cohorts within each country.

Notice that, in each country, the time trend variable $t$ takes the same value for the two cohorts. As suggested by Moulton (1990), this is bound to inflate t-values. We correct standard errors by assuming lack of independence within clusters and independence between clusters ${ }^{7}$. The results of the estimates are presented in Table 2, where the dependent variable is the college - high school wage gap. In the last three rows we report the p-values associated to three Wald tests: the first statistic tests the joint significance of country effects, the second statistic tests the joint significance of the interactions between country

\footnotetext{
6 See Table A1 in the Appendix

${ }^{7}$ In practice, this is done by using the option cluster in the command regress of Stata 6.0. Each cluster is obtained by combining the country with the year.
} 
and cohort dummies and the last statistic tests the joint significance of the interactions among the linear trend, the country and the cohort dummies. In each test, the null hypothesis is lack of joint significance. All tests turn out to reject the null hypothesis. We draw from this three implications: first, there are significant cross country differences within Europe in the level and growth of the college wage gap; second, and conditional on the aggregate time effects, there are significant cohort effects in European college wage gaps; last but not least, the growth of these gaps also differ between cohorts.

Examining our results more in detail, we find that: 1) the intercept, which captures the country effect for the older cohort, is relatively high in Germany and Austria and relatively low in Denmark, Italy, Portugal and the UK; 2) the interaction between the intercept and the cohort dummy is negative in most countries, with the exception of Portugal, France and Italy. A negative coefficient can be explained by the presence of an age effect and by the fact that age - earnings profiles have a positive slope. A positive coefficient suggests a shift in age - earnings profiles in favor of the younger generation; 3) the estimated trend in the college wage gap for the older cohort is positive in all countries but The Netherlands. The trend is particularly pronounced in Finland, Portugal, and Italy; 4) the estimated trend in the college wage gap is higher for the younger than for the older cohort in Austria, Denmark, The Netherlands, Switzerland and the UK (see Figure 4) and lower in the rest of the sample ${ }^{8}$.

We stress two results in particular. First, and in contrast to the evidence presented by Card and Lemieux (2000) on three Anglo-Saxon countries, the growth of the college wage gap in Europe has not been limited to the younger cohort, with the exception of three relatively small countries, Austria, Switzerland and The Netherlands, and possibly of the UK. Second, there is evidence that in a number of European countries the college wage gap has risen at least as fast for the older as for the younger cohort.

\footnotetext{
${ }^{8}$ The difference between cohorts is statistically significant at the 10 percent level of confidence in Austria, Denmark and The Netherlands.
} 
Table 2. Estimates of the statistical model. Weighted ordinary least squares. Weights: average number of high school and college employees, by country and cohort.

\begin{tabular}{lcc}
\hline \hline & College - High School & Wage Gap \\
\hline Independent Variable & Coefficient & P-value \\
\hline Constant & .377 & .000 \\
Austria & .129 & .006 \\
Denmark & -.222 & .000 \\
Finland & -.021 & .300 \\
France & -.070 & .001 \\
Italy & -.171 & .027 \\
Netherlands & -.079 & .043 \\
Portugal & -.247 & .000 \\
Switzerland & -.059 & .073 \\
Uk & -.173 & .000 \\
Austria $* t$ & .002 & .471 \\
Denmark $* t$ & .006 & .000 \\
Finland $* t$ & .014 & .000 \\
France $* t$ & .002 & .039 \\
Germany $* t$ & .006 & .003 \\
Italy $* t$ & .012 & .169 \\
Netherlands $* t$ & -.009 & .060 \\
Portugal $* t$ & .017 & .004 \\
Switzerland $* t$ & .002 & .642 \\
Uk $* t$ & .008 & .007 \\
Austria $* C$ & -.218 & .000 \\
Denmark $* C$ & -.098 & .000 \\
Finland $* C$ & -.015 & .684 \\
France $* C$ & .046 & .000 \\
Germany $* C$ & -.008 & .758 \\
Italy $* C$ & .022 & .721 \\
Netherlands $* C$ & -.146 & .002 \\
\hline \hline & &
\end{tabular}


Table 2 (continued)

\begin{tabular}{lcc}
\hline \hline & College -High School & Wage Gap \\
\hline Independent Variable & Coefficient & P-value \\
\hline Portugal $* C$ & .237 & .000 \\
Switzerland $* C$ & -.043 & .118 \\
Uk $* C$ & -.047 & .602 \\
Austria $* t * C$ & .005 & .038 \\
Denmark $* t * C$ & .007 & .001 \\
Finland $* t * C$ & -.005 & .337 \\
France $* t * C$ & -.001 & .593 \\
Germany $* t * C$ & -.003 & .221 \\
Italy $* t * C$ & -.009 & .229 \\
Netherlands $* t * C$ & .011 & .104 \\
Portugal $* t * C$ & -.009 & .229 \\
Switzerland $* t * C$ & .006 & .276 \\
Uk $* t * C$ & .005 & .543 \\
& & \\
\hline Nobs & 179 & \\
$\mathrm{R}^{2}$ & .880 & \\
Test 1 & .000 & \\
Test 2 & .000 & \\
Test 3 & .009 & \\
\hline \hline Note: the constant term refers to the older cohort in Germany.
\end{tabular}

We also find that there is a negative correlation (-0.356) between the estimated time invariant country by cohort effect (intercept) and the time varying country by cohort aggregate effect (see Figure 5). This suggests that countries that started with relatively high college wage gaps have also experienced a slower growth in the gap during the sample period.

The observed heterogeneity in the behavior of the college wage gap among countries, between cohorts and over time begs the question whether these differences can be associated to differences in the levels and changes of relative supply, relative demand and institutional setups. We try to answer this question in the next and final section of the paper. 


\section{Accounting for differences}

A model that combines labor market competition with non - competitive rents implies that cross country differences in the college wage gap should be correlated with differences in relative demand, relative supply and institutional setups. Correlation does not imply a causal relationship, however, because relative prices and quantities are jointly determined in competitive markets and institutions themselves could vary in response to price and quantity signals (see the discussion in Fortin and Lemieux (1995)).

We summarize the discovered differences in college wage gaps with two indicators: 1) the estimated coefficient of the country dummy ( $L)$, that varies between cohorts and captures time invariant effects on the college wage gap; 2 ) the estimated coefficient of the time trend $(T)$, that varies by country and cohort and captures aggregate time effects. Next, we relate each indicator to measures of relative supply, relative demand and labor market institutions. Following Fortin and Lemieux (1997) and Gottschalk and Smeeding (1997), we associate the former indicator $(L)$ to relative supply, demand and to the levels of institutional constraints affecting the wage gap and the latter indicator $(T)$ to changes in relative supply, demand and institutional constraints. We start the section by describing in some detail our measures of relative supply, demand and institutional factors. We then turn to exploring how these measures correlate with the college wage gap.

Since our data on the wage gap cover the mid 1980s for some countries and the 1990s for all countries, we need to compute measures of relative supply and relative demand that broadly cover the same span of time. Consider first relative supply. We measure supply by educational level (compulsory, upper secondary and tertiary) by using educational attainment in the population aged 25 to 64 . The source is OECD (1998) for 1991 onwards. With no data for the 1980s, we proceed as follows. First, we use the Barro and Lee (1996) dataset on educational attainment, that provides data on completed education every 5 years from 1965 to 1990. Next, we compute for each country the annual rate of 
growth of attainment before 1990 by interpolating the available data points with a fourth order polynomial. Finally, we apply the estimated rate of growth to the OECD data in 1991 to compute attainment in the 1980s. While this method suffers of measurement problems, some of these problems are swept away by taking averages over the whole sample period.

Table 3 shows average educational attainment for each country. Notice the large differences in the relative importance of compulsory and higher education, especially between the two Mediterranean countries (Italy and Portugal), where compulsory education is still the highest attainment for the majority of the active population, and Northern Europe.

Table 3. Average educational attainment. By country.

\begin{tabular}{lcccc}
\hline \hline & Compulsory & Upper Secon. & Tertiary & Sample period \\
\hline Austria & .337 & .595 & .067 & $85-97$ \\
Denmark & .442 & .381 & .175 & $85-95$ \\
Finland & .384 & .436 & .179 & $87-93$ \\
France & .419 & .406 & .174 & $90-98$ \\
Germany & .218 & .567 & .214 & $85-97$ \\
Italy & .682 & .246 & .070 & $87-98$ \\
Netherlands & .437 & .367 & .195 & $86-96$ \\
Portugal & .932 & .031 & .036 & $85-93$ \\
Switzerland & .186 & .597 & .217 & $92-98$ \\
UK & .390 & .459 & .150 & $85-95$ \\
\hline \hline
\end{tabular}

We measure changes in relative supply $\Delta S$ with the average annual rates of change in relative attainment. Table 4 shows these average rates by country from the mid 1980s onwards. The growth in the relative supply of college graduates has been faster during this period in Austria, Finland and Italy and slowest in Denmark, France and Germany.

When workers belonging to different cohorts are not perfect substitutes, the time invariant component of the college wage gap depends on the cohort specific relative supply of college graduates, $\frac{H_{j c}}{S_{j c}}$. In the absence of supply data disaggregated by cohort, we use relative cohort size, that includes only employed workers by educational attainment. 
Table 4. Average Percentage Changes in Relative Supply. By country.

\begin{tabular}{lc}
\hline \hline & $\Delta S$ College -High School \\
\hline \hline Austria & .119 \\
Denmark & .008 \\
Finland & .068 \\
France & .015 \\
Germany & .014 \\
Italy & .072 \\
Netherlands & .035 \\
Portugal & .020 \\
Switzerland & .019 \\
UK & .022 \\
\hline \hline
\end{tabular}

In this literature, the standard measure of relative demand shifts is based on the Katz and Murphy (KM) index (see Katz and Murphy (1992) and Berman et al (1994)). This index weights between industries employment changes with the relative importance of educational groups in each industry. As explained in the Data Appendix, we use the single digit ISIC classification, that allocates industries to 9 broad sectors, and compute the employment share of each educational group in each industry using the 1996 wave of the European Community Household Panel (ECHP) ${ }^{9}$. Employment data are from the OECD Labor Force Statistics. For each country we have selected two data points in the 1980s and two data points in the 1990s to minimize structural changes in the definition of data and sectors and have computed the KM index for each pair of years. To obtain a yearly measure of demand shifts by educational attainment, we have divided the index by the length of the time interval. The final indicator of relative demand shifts is $\Delta D=\ln \left(1+K M_{u}\right)-\ln \left(1+K M_{s}\right)$, where the subscripts $s$ and $u$ are respectively for high school and college (see Blau and Kahn (1996)). Table 5 shows the value of $\Delta D$ for the 10 European countries. With the exception of The Netherlands, relative between industries demand shifts over the sample period have been in favor of college graduates, particularly so in Austria and France.

\footnotetext{
${ }^{9}$ These data were made available by the European Comminity for research related to the TSER project on returns to education in Europe (PURE).
} 
Galor and Moav (2000) have recently shown that relative wages by education and skill can be affected by the rate of technical progress. By introducing new vintages of techniques, technical progress has both a productivity and an erosion effect on skills and wages. Erosion occurs because accumulated skills depreciate with the introduction of new techniques and the progressive demise of old techniques. If the skills of high school graduates depreciate faster than the skills of college graduates, the college wage gap increases when technical progress accelerates. We proxy the rate of technical progress with the 1976 to 1992 average rate of growth of labor productivity $g$, that is shown in the last column of Table $5^{10}$.

Table 5. Relative demand shifts (x100) and average productivity growth. By country.

\begin{tabular}{lcc}
\hline \hline & $\Delta D$ College - High School & Productivity Growth $g$ \\
\hline \hline Austria & 1.80 & .015 \\
Denmark & 0.17 & .012 \\
Finland & 0.36 & .019 \\
France & 1.09 & .014 \\
Germany & 0.04 & .014 \\
Italy & 0.43 & .022 \\
Netherlands & -0.93 & .008 \\
Portugal & 0.08 & .028 \\
Switzerland & 0.45 & .011 \\
UK & 0.49 & .018 \\
\hline \hline
\end{tabular}

We hasten to stress that a positive correlation between the college wage gap and labor productivity growth is consistent with at least three alternative stories. First, skill biased technical change that increases productivity growth can affect the college wage gap by shifting out the relative demand for skilled labor. The shift can be both between and within industries. Since we already control for between effects with the variable $\Delta D, g$ could be picking up the within industries effect of skill biased technical change (see Berman et al. (1994), (1998)). Second, labor productivity growth could be driven, at least in part,

\footnotetext{
${ }^{10}$ These data are from Layard and Nickell (1997).
} 
by the growth in the capital - labor ratio; if capital and skill are complements in production, this would generate an upward shift in the relative demand for skills (see Krusell et al (2000)). Last but not least, both a higher college wage gap and faster skill biased technical progress could be induced by the relative abundance of well educated labor (Acemoglu (2000)).

Labor market institutions that potentially affect non - competitive rents and the college wage gap include measures of union power, the presence and importance of a minimum wage and the degree of centralization of the wage bargain (Katz and Autor, 2000). Since institutions vary over time, we distinguish between levels at the start of the sample period and changes over the sample period.

Starting with levels, Table 6 presents data on four institutional measures: the Kaitz index $(K)$, defined as the ratio of the minimum wage to the average wage ${ }^{11}$; union density in 1980 (U80); an index of the degree of centralization of the wage bargain (Centra80) for the early 1980s; and an index of the relative strictness of employment protection measures, also for the 1980s (EPL80) ${ }^{12}$. When possible, we measure institutional variables in the early 1980s to minimize the risk of endogeneity.

Table 6. Institutional changes over the sample period. By country.

\begin{tabular}{lcccc}
\hline \hline & U80 $(\%)$ & EPL80 & Centra 80 & $K$ \\
\hline \hline Austria & 56 & 4 & 2 & .62 \\
Denmark & 76 & 3 & 2 & .54 \\
Finland & 70 & 5 & 1 & .52 \\
France & 18 & 6 & 3 & .50 \\
Germany & 36 & 8 & 3 & .55 \\
Italy & 49 & 9 & 4 & .71 \\
Netherlands & 35 & 7 & 3 & .55 \\
Portugal & 61 & 10 & 4 & .45 \\
Switzerland & 31 & 3 & 3 & .52 \\
UK & 50 & 1 & 3 & .40 \\
\hline \hline
\end{tabular}

${ }^{11}$ Source: Layard and Nickell (1997).

${ }^{12}$ Source for the last three measures: OECD Employment Outlook 1999. 
Union density is a measure of union influence on relative wages. Traditionally, stronger unions have compressed wage differentials by skill and education and we expect this measure to be negatively correlated with the time invariant component of the college wage gap ${ }^{13}$. Similarly, we expect a negative correlation between the Kaitz index and the college wage gap, because a relatively high minimum wage can raise wages in the lower end of the wage distribution and thus affect the denominator of the gap.

The relationship between the degree of centralization of the bargain and the college wage gap is less clear-cut. Calmfors (1993), for instance, uses a simple two sectors model of a unionized economy to show that a higher degree of centralization is associated to a less dispersed wage structure only if particular restrictions on union preferences are imposed. Therefore, one should not expect a priori that economies with more centralized wage setting institutions necessarily have lower college wage gaps. The OECD index ranks countries by level of centralization, with Finland the most centralized and Italy and Portugal the less centralized.

Relative compression of the wage structure is often associated to strict employment protection practices. As argued by Bertola and Rogerson (1997), quantitative firing restrictions could hardly be binding if wages were completely unrestrained and employers could reduce them so as to make stable employment profitable. Limiting the freedom offered to employers and workers in setting wages give force to these constraints ${ }^{14}$. The OECD index of employment protection ranks Italy and Portugal as the countries with the most restrictive practices and the UK, Denmark and Switzerland as the countries with less protection.

Table 7 focuses on changes between the 1980s and the 1990s in three institutional variables, the degree of centralization, employment protection and

\footnotetext{
${ }^{13}$ See Freeman (1993) and Freeman and Gibbons (1995).

${ }^{14}$ The combination of wage compression and employment protection measures may reflect "..a desire by organized labor to enforce monopolistic wage-setting practices by preventing underbidding by the unemployed.." (Bertola, Boeri and Cazes (1999)) and is a powerful source of insider power.
} 
union density ${ }^{15}$. For the former two variables, we use the OECD dataset on institutional changes ${ }^{16}$ and code no change with a 0 , an increase with a 1 and a reduction with a -1 . For the latter variable, we take the average annual change in union density over the sample period. The degree of centralization has declined in the UK, Denmark and Finland and increased in Italy and Portugal. On the other hand, employment protection has declined in most countries with the exception of Austria, Switzerland and the UK, where it has remained stable, and France, where it has increased. Finally, union density has declined in the majority of countries, with the exception of Denmark, Finland and The Netherlands, where it has increased, albeit at different rates.

Table 7. Institutional changes over the sample period. By country.

\begin{tabular}{lccc}
\hline \hline & $\Delta$ Centra & $\Delta U(\%)$ & $\Delta E P L$ \\
\hline \hline Austria & 0 & -4.03 & 0 \\
Denmark & -1 & 0.24 & -1 \\
Finland & -1 & 2.63 & -1 \\
France & 0 & -0.13 & 1 \\
Germany & 0 & -1.86 & -1 \\
Italy & 1 & -3.91 & -1 \\
Netherlands & 0 & 0.39 & -1 \\
Portugal & 1 & -10.04 & -1 \\
Switzerland & 0 & -0.70 & 0 \\
UK & -1 & -2.60 & 0 \\
\hline \hline
\end{tabular}

We use the estimated parameters of the trend in the college wage gap $T$ and of the time invariant country effect $L$ in Table 2 as our observations. With 10 countries and 2 cohorts, we have 20 observations for each variable. We regress $T$ on the changes and $L$ on the levels of relative supply, demand and institutional constraints. In each regression, we compute standard errors by assuming lack of independence of observations within countries and independence across countries. The regressions are weighted in two alternative ways. First, we weigh each observation with the country and cohort - specific average number of high

\footnotetext{
${ }^{15}$ We have no data on changes in the Kaitz index that cover all countries.

${ }^{16}$ See OECD, Employment Outlook 1999.
} 
school and college employees; second, we weigh with the country - specific male population in 1990. While the former set of weights includes only employed individuals belonging to the two selected cohorts, the latter set is a more comprehensive measure of overall country size, but does not vary by cohort. Table 8 presents our results for the estimated growth in the college - high school wage gap.

Table 8. Estimates of the relationship between $T$ and changes in relative demand, supply and institutional variables. Dependent variable: $T$

\begin{tabular}{l|c|c|c|c}
\hline \hline & Coefficient & P-value & Coefficient & P-value \\
\hline \hline & $(1)$ & $(1)$ & $(2)$ & $(2)$ \\
\hline Cohort Dummy & .001 & .51 & -.001 & -.33 \\
$\Delta S$ & -.052 & .06 & -.028 & .11 \\
$g$ & .488 & .07 & .731 & .00 \\
$\Delta D$ & .309 & .20 & .288 & .03 \\
$\Delta E P L$ & -.004 & .02 & -.003 & .02 \\
$\Delta U$ & -.049 & .04 & -.033 & .22 \\
$\Delta$ Centra & -.003 & .02 & -.003 & .00 \\
& & & & \\
\hline$R^{2}$ & .68 & & .63 & \\
Nobs & 20 & & 20 & \\
\hline \hline
\end{tabular}

Note: each regression also includes a constant term. (1) weights: average number of high school and college employees, by country and cohort; (2) weights: male population in 1990 .

The table shows that the estimated growth in the college - high school wage gap $T$ is negatively correlated with changes in relative supply and positively correlated both with the index of between industry demand shocks and with the rate of productivity growth, as expected. Interestingly, institutional changes are significantly correlated with $T$. In particular, there is evidence that countries that have experienced a decline in union density, in the centralization of the wage bargain and in employment protection measures have also had a faster growth in the college wage gap ${ }^{17}$.

\footnotetext{
${ }^{17}$ Table A2 in the Appendix shows that results do not change in a qualitative way when we use the college - less than college gap.
} 
To illustrate our results with an example, compare Portugal and The Netherlands, the countries with the highest and lowest estimated $T$. Relative supply changes have been smaller and productivity growth much faster in Portugal than in The Netherlands. Moreover, between industries demand shifts have been positive in Portugal and negative in The Netherlands. Both countries have experienced a decline in employment protection, but Portugal has also witnessed a relevant decline in union density and an increase in centralization, that have either increased or remained constant in the Netherlands. When we decompose predicted $T$ into the contributions of relative supply changes $(\Delta S)$, relative demand changes $(\Delta D$ and $g)$ and institutional changes $(\triangle U, \triangle E P L$ and $\Delta$ Centra), we find that the relative contribution of relative demand changes has been particularly significant in Portugal. On the other hand, the largest absolute contribution to predicted $T$ in The Netherlands has originated from institutional changes.

We also compare France, Germany and the UK. France has the lowest and the UK the highest estimated $T$, with Germany in the middle. Both relative supply shifts and the rate of long run productivity growth have been larger in the UK. Partially to offset this, the index of between industries demand shifts in France has been more than twice as high as in Britain and much higher than in Germany. A possible interpretation is that within industries demand shifts have been relatively more important than between industries demand shifts in the UK and Germany than in France. Moreover, the UK has experienced both a decline in centralization and the highest reduction in union density over the sample period. Finally, employment protection has increased in France, declined in Germany and remained constant in the UK. A decomposition of predicted $T$ shows that the absolute contribution of relative demand shifts has been quite similar in Britain and in France. The key difference between the two countries is the absolute contribution of institutional changes to predicted $T$, that has been positive in Britain and negative in France. Therefore, while relative demand shocks have equally contributed to increase the growth of the college wage gap in both countries, institutional changes have contributed to increase growth in 
the former country and to reduce it in the latter country. In Germany, the absolute contribution of relative demand shifts has been smaller than in the other two countries. On the other hand, institutional changes have contributed as much as in Britain to the positive predicted trend in the college wage gap.

Labor market institutions need not affect the two cohorts in the same way. We allow for differential effects by interacting each institutional variable with the cohort dummy. With few observations, we retain a parsimonious specification by sequentially eliminating institutional variables and interactions that attract an insignificant coefficient. Table 9 illustrates our results. We find that both the change in union density and the change in the degree of centralization are negatively and significantly correlated with the estimated growth in the college wage gap of the younger cohort born between 1950 and 1959. There is no trace of a significant correlation between these variables and the trend in the college wage gap of the older cohort.

Both a change in the unionization rate and a change in the degree of centralization are expected to affect the college wage gap by influencing the average wage of high school workers, who are more likely to be unionized and to have their pay regulated by collective bargaining. The uncovered absence of a significant correlation between these changes and the trend in the college wage gap for the older cohort suggests either an insider - outsider or an internal labor market story (see Katz and Autor (1999) for a discussion). In either story, senior high school workers, who belong mainly to the older cohort, are sheltered by seniority rules from the economic effects of institutional changes.

Next, we briefly consider how the estimated country dummy $L$ varies with relative supply, demand and the levels of institutional constraints. We measure cohort - specific relative supply with relative cohort size, relative demand both with the 1991 employment share of the finance, insurance and business services sector (ISIC classification 8), that employs a relatively high proportion of college graduates, and with the OECD high tech index, that measures the export share of high tech industries in total manufacturing ${ }^{18}$, and use Centra80, EPL80, $K$

${ }^{18}$ Source: OECD (1994). 
and $U 80$ as institutional variables. We also add cohort specific average age at the beginning of the sample period, $A_{o}$.

Table 9. Estimates of the relationship between $T$ and changes in relative demand, supply and institutional variables. Dependent variable: $T$. Includes interactions with the cohort dummy.

\begin{tabular}{l|c|c|c|c}
\hline \hline & Coefficient & P-value & Coefficient & P-value \\
\hline \hline & $(1)$ & $(1)$ & $(2)$ & $(2)$ \\
\hline Cohort Dummy & -.0004 & -.24 & .001 & .56 \\
$\Delta S$ & -.052 & .03 & -.037 & .03 \\
$g$ & .509 & .03 & .841 & .00 \\
$\Delta D$ & .320 & .14 & .267 & .03 \\
$\Delta E P L$ & -.004 & .01 & -.003 & .01 \\
$\Delta U *$ Cohort Dummy & -.081 & .04 & -.017 & .78 \\
$\Delta$ Centra $*$ Cohort Dummy & -.006 & .02 & -.006 & .00 \\
& & & & \\
\hline$R^{2}$ & .76 & & .80 & \\
Nobs & 20 & & 20 & \\
\hline \hline
\end{tabular}

Note: see Table 8.

Table 10 presents the results of our parsimonious specification, obtained after sequential simplification. We find that relative demand variables, Centra 80 and $U 80$ have no significant effect on $L$. As expected, the time invariant country effect is negatively correlated both with cohort size and with the Kaitz index. The positive correlation with age at the start of the sample period is also expected and suggests that college graduates have steeper earnings profiles than high school graduates.

Table 10. Estimates of the relationship between $L$, relative demand, supply and institutional variables. Dependent variable: $L$

\begin{tabular}{lc|c|c|c}
\hline \hline & Coefficient & P-value & Coefficient & P-value \\
\hline \hline & $(1)$ & $(1)$ & $(2)$ & $(2)$ \\
\hline Cohort Dummy & .129 & .02 & .143 & .00 \\
Relative Cohort Size & -.173 & .00 & -.146 & .00 \\
Age at start & .019 & .00 & .016 & .00 \\
$K$ & -1.356 & .00 & -1.072 & .00 \\
$E P L 80$ & .018 & .00 & .012 & .00 \\
\hline$R^{2}$ & .75 & & .83 & \\
Nobs & 20 & & 20 & \\
\hline \hline
\end{tabular}


Note: see Table 8.

Conditional on initial age, the cohort dummy attracts a positive and significant coefficient, suggesting an upward shift in the earnings profiles of college graduates who belong to the younger cohort. Contrary to our expectations, however, there is evidence of a positive and significant correlation with the degree of employment protection in the $1980 \mathrm{~s}^{19}$. To illustrate, consider Germany and the UK. The average value of $L$ in Germany is almost twice as large as in the UK. This difference is accounted for by the higher average age at the start of the sample period and by the lower relative cohort size in Germany, the effects of which are only partially offset by the opposite effects of a lower Kaitz index and of lower employment protection in the UK.

\section{Concluding Remarks}

Card and Lemieux (2000) have shown that the recent increase of the college wage gap in the US (and Britain) is almost completely attributable to changes in the relative earnings of the younger cohorts of college graduates. In this paper, we have used cohort data for two contiguous birth cohorts in 10 European countries to study whether similar findings hold in Europe. We do not find evidence of a common European pattern. Only in three relatively small European countries (Austria, Switzerland and the Netherlands) and possibly in the UK is the increase in the college wage gap almost exclusively limited to the younger cohort, as in the US. In Denmark, there is evidence that the college wage gap has increased for both the older and the younger cohort, but faster for the latter. The evidence for the three major continental European countries goes in the opposite direction, because the college wage gap has increased faster during the 1980s and the 1990s for the older cohort born between 1940 and 1949 than for the younger cohort born between 1950 and 1959 .

\footnotetext{
${ }^{19}$ The results for the college - less than college gap are shown in Table A3 in the Appendix. In this case, there is also evidence that the time invariant component of the gap is negatively correlated with union density, the degree of centralization and the share of public employment $S H A$.
} 
We have used the cross country variation in relative supply, demand and institutional constraints to investigate whether changes in these variables are correlated with the estimated trend in the college wage gap. It turns out that the trend in the gap is negatively correlated to changes in relative supply and positively correlated both with the long run rate of productivity growth and with an index of between industry demand shocks. Institutional changes also matter, and we have found that countries that have experienced declines in union density, in the centralization of the wage bargain and in employment protection measures have also had a faster growth in the college wage gap.

\section{Data Appendix}

Table B1 presents some details on the data used in this paper. The original data were drawn from individual micro surveys by PURE partners and collapsed into cohort data by using in a homogeneous frame. Hourly wages are gross of taxes for all countries with the exception of Austria and Italy.

Table A1. Data sources

\begin{tabular}{|c|c|c|}
\hline Country & Source & Sample period \\
\hline Austria & Mikrocensus & $1981-97$ \\
\hline Denmark & Longitudinal Labor Market Register & 1980-95 \\
\hline Finland & Labor Force Survey & $1987-93$ \\
\hline France & INSEE Emploi & 1990-98 \\
\hline Germany & GSOEP & $1984-97$ \\
\hline Italy & SHIW & $1987-98$ \\
\hline Netherlands & OSA Panel & $1986-98$ \\
\hline Portugal & Quadros de Pessoas & $1983-93$ \\
\hline Switzerland & Labour Force Survey & 1992-98 \\
\hline UK & Family Expenditure Survey & $1980-95$ \\
\hline
\end{tabular}

The Katz and Murphy (1992) between industry demand shift index is based on equation (14) of their original paper

$$
\Delta X_{k}^{d}=\sum_{j}\left(\frac{E_{j k}}{E_{j}}\right)\left(\frac{\Delta E_{j}}{E_{k}}\right)=\frac{\sum_{j} \alpha_{j k} \Delta E_{j}}{E_{k}}
$$


where $k$ is for the educational group, $j$ for the industrial sector, $E$ is for employment and $\alpha$ is the weight of the educational group in the industry. The original 9 ISIC sectors were reduced to 8 by aggregating mining and quarring with electrical production. This aggregation was necessary to obtain a classification as close as possible to the one employed by the European Ccommunity Household Panel (EHCP). The 8 sectors are: Agriculture, Mining plus Electricity, Manufacturing, Construction, Wholesale and Retail Trade, Transport and Communication, Finance and Insurance and Business Services and Community, Social and Personal Services. 


\section{Appendix}

The College - Less than College Wage Gap

Table A1. College/Less than College. Males only. Cohort specific and aggregate changes

\begin{tabular}{l|ccc|ccc|c|c}
\hline \hline & \multicolumn{3}{|c|}{ Born 40-49 } & \multicolumn{3}{c|}{ Born 50-59 } & All cohorts & Years \\
\hline & $80 \mathrm{~s}$ & $90 \mathrm{~s}$ & $\Delta$ & $80 \mathrm{~s}$ & $90 \mathrm{~s}$ & $\Delta$ & $\Delta$ & \\
\hline Austria & .593 & .566 & -5.5 & .347 & .405 & 16.7 & -13.4 & $85-97$ \\
Denmark & .231 & .337 & 45.8 & .163 & .308 & 88.9 & 26.3 & $85-95$ \\
Finland & .452 & .505 & 11.7 & .394 & .404 & 2.5 & 3.2 & $87-93$ \\
France & .482 & .466 & -3.3 & .448 & .440 & -1.8 & -9.3 & $90-98$ \\
Germany & .407 & .488 & 19.9 & .391 & .433 & 10.7 & -2.5 & $85-97$ \\
Italy & .337 & .486 & 44.5 & .325 & .376 & 15.7 & 12.0 & $87-98$ \\
Netherlands & .353 & .370 & 4.8 & .226 & .327 & 44.7 & 16.7 & $86-96$ \\
Portugal & .891 & 1.085 & 21.1 & .786 & 1.065 & 35.5 & 23.6 & $85-93$ \\
Switzerland & .382 & .390 & 2.1 & .310 & .362 & 16.8 & 7.9 & $92-98$ \\
UK & .415 & .461 & 11.1 & .298 & .418 & 40.3 & 13.3 & $85-95$ \\
\hline \hline
\end{tabular}

Notes: see table 1.

Table A2. Estimates of the relationship between $T$ and changes in relative demand, supply and institutional variables. Dependent variable: $T$

\begin{tabular}{l|c|c}
\hline \hline & C-LC \\
\hline \hline & Coefficient & P-value \\
\hline Cohort Dummy & .002 & .04 \\
$\Delta S$ & -.110 & .06 \\
$g$ & .758 & .04 \\
$\Delta E P L$ & & \\
$\Delta U$ & -.005 & .01 \\
$\Delta$ Centra & -.282 & .01 \\
& - & - \\
\hline$R^{2}$ & & \\
Nobs & .95 & \\
\hline \hline
\end{tabular}

Note: each regression also includes a constant term. Weights: average number of high school and college employees, by country and cohort. 
Table A3. Estimates of the relationship between $L$, relative demand, supply and institutional variables. Dependent variable: $L$

\begin{tabular}{l|c|c}
\hline \hline & \multicolumn{2}{|c}{ C-LC } \\
\hline \hline Cohort Dummy & Coefficient & P-value \\
Relative Cohort Size & .099 & .06 \\
Age at start & -.133 & .00 \\
Share of public empl. & .017 & .00 \\
$K$ & -.606 & .00 \\
U80 & -1.051 & .00 \\
Centra80 & -.171 & .04 \\
EPL80 & -.034 & .02 \\
\hline$R^{2}$ & .016 & .02 \\
Nobs & .94 & \\
\hline \hline
\end{tabular}

Note: see Table A.2 


\section{References}

[1] Acemoglu, D., (2000), Technical Change, Inequality and the Labor Market, NBER Working paper \# 7800, Cambrisge, MA.

[2] Barro, R. and Lee, J., (1996), "International Measures of Schooling Years and Schooling Quality", The American Economic Review, 73, 928-46.

[3] Blau, F.D. and Kahn, L.M. (1996), "International Differences in Male Wage Inequality: Institutions Versus Market Forces", Journal of Political Economy, 104(4), 791-836.

[4] Berman, E., Bound, J. and Griliches, Z. (1994), "Changes in the demand for skilled labor within US manufacturing industries: evidence from the annual survey of manufactures", Quarterly Journal of Economics, 109, 367-397.

[5] Berman, E., Bound, J. and Machin, S., (1998), "Implications of skill-biased labor international evidence, Quarterly Journal of Economics, 113, 12451279 .

[6] Bertola, G., Boeri, T. and S. Cizes (2000), "Employment protection and labor market adjustment in some OECD countries: evolving institutions and variable enforcement", mimeo, European University Institute.

[7] Bertola, G. and Rogerson, R., (1997), Institutions and Labor Reallocation, The European Economic Review, 41, 1147-1171.

[8] Bound, J. and Johnson, G. (1992), "Changes in the Structure of Wages in the 1980s: an Evaluation of Alternative Explanations", American Economic Review, 82, 371-392.

[9] Calmfors, L. (1993), "Centralization of Wage Bargaining and Macroeconomic Performance: a Survey", IIES Discussion Paper \#536, Stockholm University.

[10] Card, D. and Lemieux, T. (2000), "Can Falling Supply Explain the Rising Return to College for Younger Men? A Cohort Based Analysis", National Bureau of Economic Research, WP\#7655.

[11] DiNardo, J., Fortin, N. and T. Lemieux, (1996), "Labor market institutions and the distribution of wages, 1973-1992: a semi-parametric approach, Econometrica, 64, 1001-1044.

[12] Fortin, N. and Lemieux, T. (1997), 'Institutional Change and Rising Wage Inequality', Journal of Economic Perspectives, 11(2), 75-96.

[13] Freeman, R. (1993), "How much has De-unionisation contributed to the Rise in Male Earnings Inequality?", in Danziger, S. and Gottschalk P. (eds.), Uneven Tides, Russel Sage. 
[14] Freeman, R. and Gibbons, R. (1995), "Getting Together and Breaking Apart: The Decline in Centralised Bargaining?", in Freeman, R. and Katz, L. (eds.), Differences and Changes in Wage Structures, University of Chicago.

[15] Freeman, R. and Schettkat, R. (2000), "Skill Compression, Wage Differentials and Employment: Germany versus the US, NBER Working Paper \#7610, Cambridge MA.

[16] Galor, O. and Moav, O. (2000), Ability biased Technological Transition, Wage Inequality and Economic Growth, The Quarterly Journal of Economics, 469-497.

[17] Gottschalk, P. and Smeeding, T. (1997), "Cross-national Comparisons of Earnings and Income Inequality", Journal of Economic Literature, 35, 633687.

[18] Katz, L.F. and Author, D.H. (1999), "Changes in the Wage Structure and Earnings Inequality", in Ashenfelter, O. and Card, D. (eds.), Handbook of Labor Economics, Vol.3, North-Holland, 1463-1555.

[19] Katz, L.F. and Murphy K.M. (1992), "Changes in the relative wages, 197387: supply and demand factors", Quarterly Journal of Economics.

[20] Krusell, P., Ohanian, L., Rios-Rull, J. and Violante, G., (2000), Capital Skill Complementarity and Inequality: A Macroeconomic Analysis, Econometrica, 1029-1053.

[21] Layard, R. and Nickell, S., (1997), "Labour Market Institutions and Economic performance", Centre for Economic Performance Discussion Paper \#23, Oxford University.

[22] Manning, A. and Manacorda, M. (2000), "Just Can’t Get Enough: More on Skill-biased Change and Labour Market Performance", Centre for Labor Market Performance, LSE.

[23] Moulton, B. (1990), "An Illustration of a Pitfall in Estimating the Effects of Aggregate Variables on Micro Units", The Review of Economics and Statistics, 334-338.

[24] OECD (1996) Employment Outlook, Paris.

[25] OECD (1994), The Jobs Study, Paris.

[26] OECD (1998) Education at a Glance, Paris. 


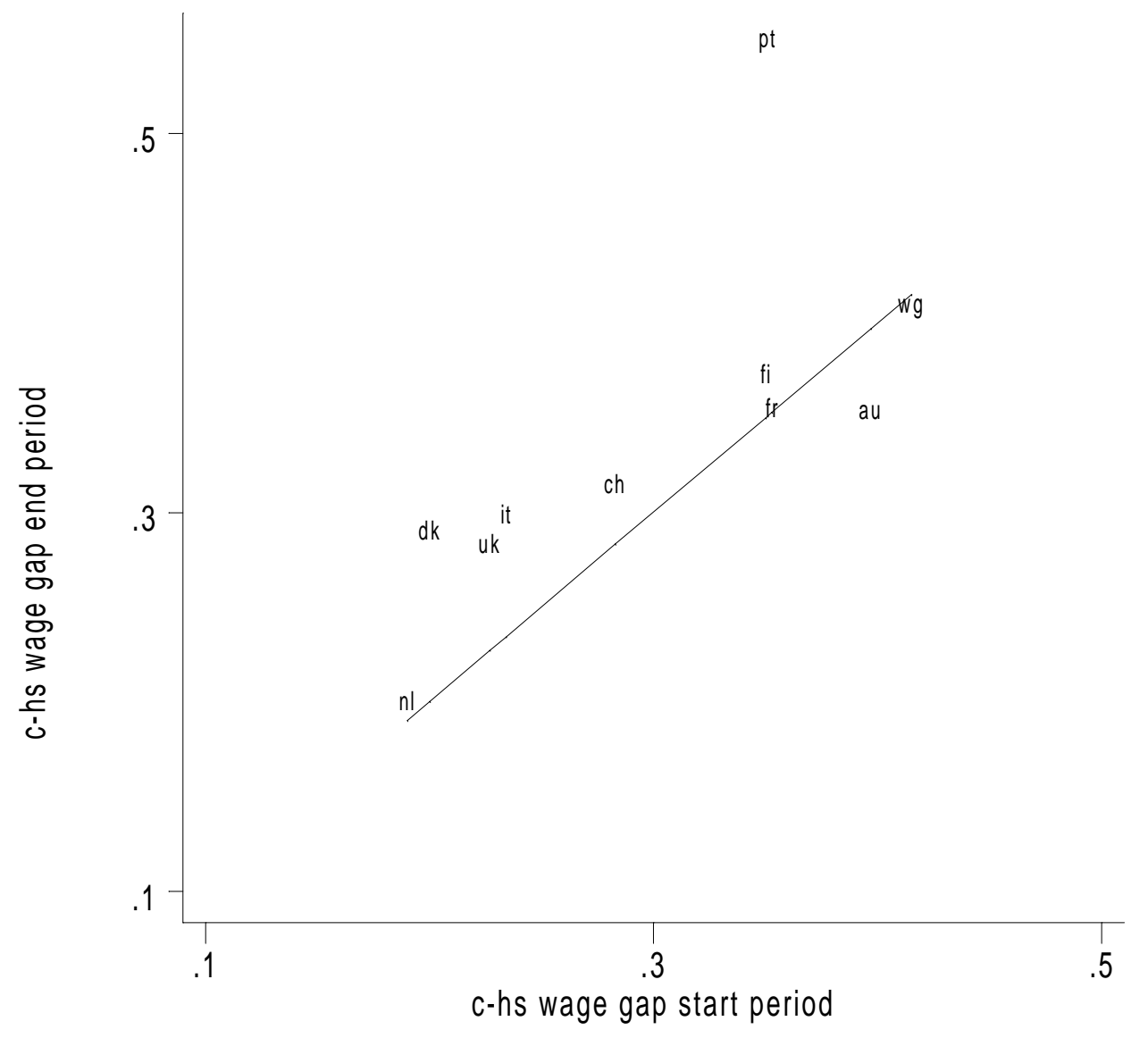

Figure 1: College - High School Wage Gap. All Cohorts 


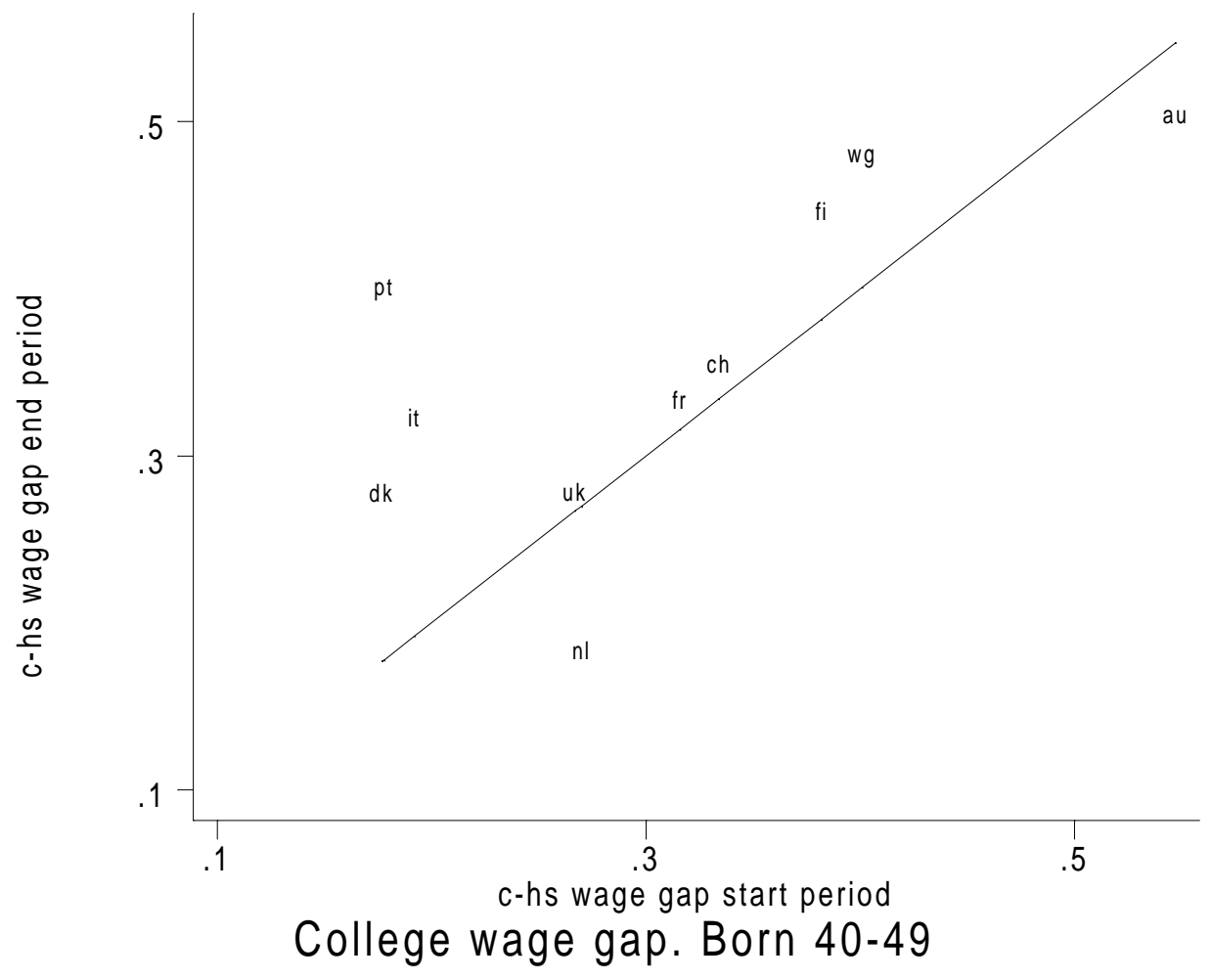

Figure 2: 


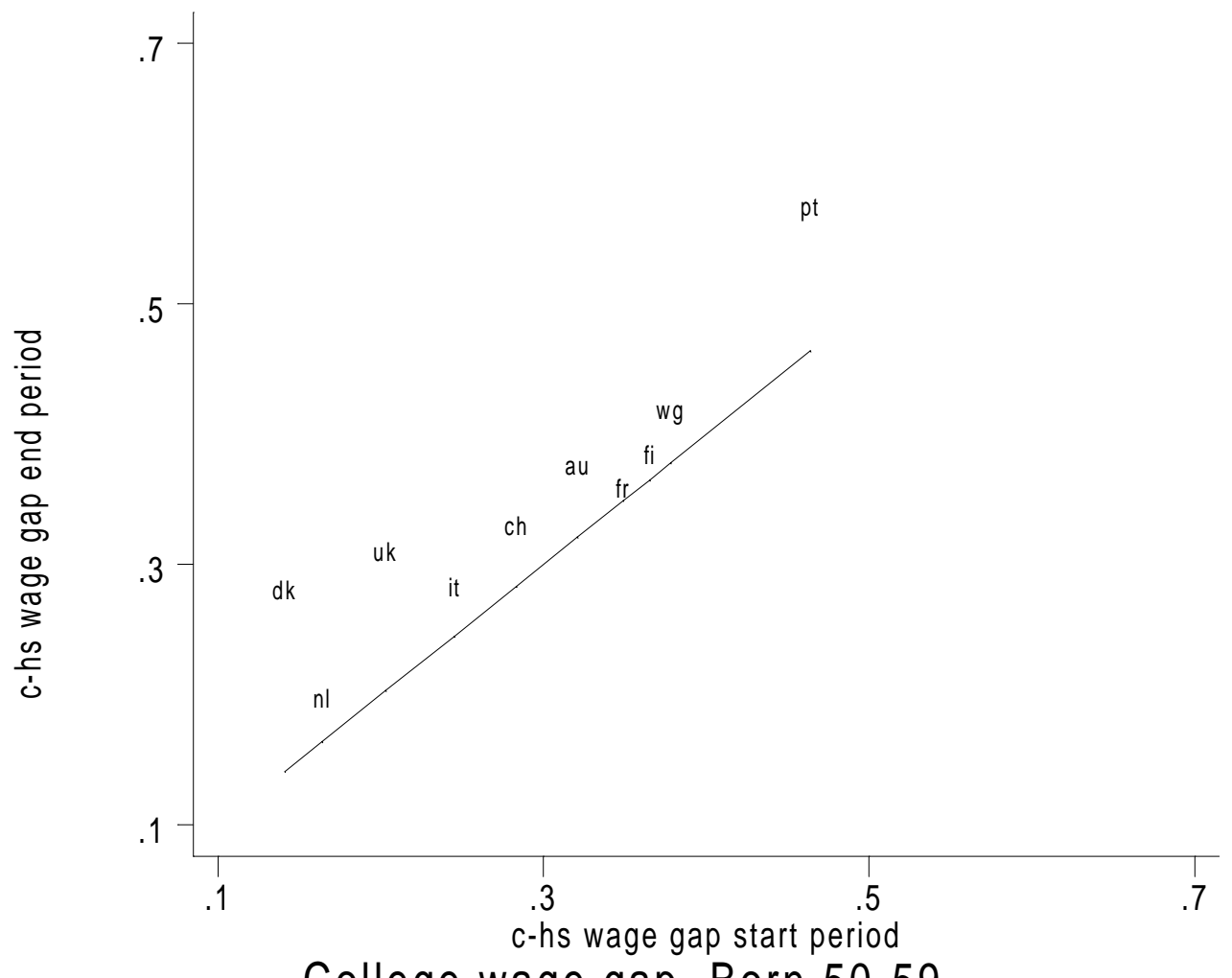

College wage gap. Born 50-59

Figure 3: 


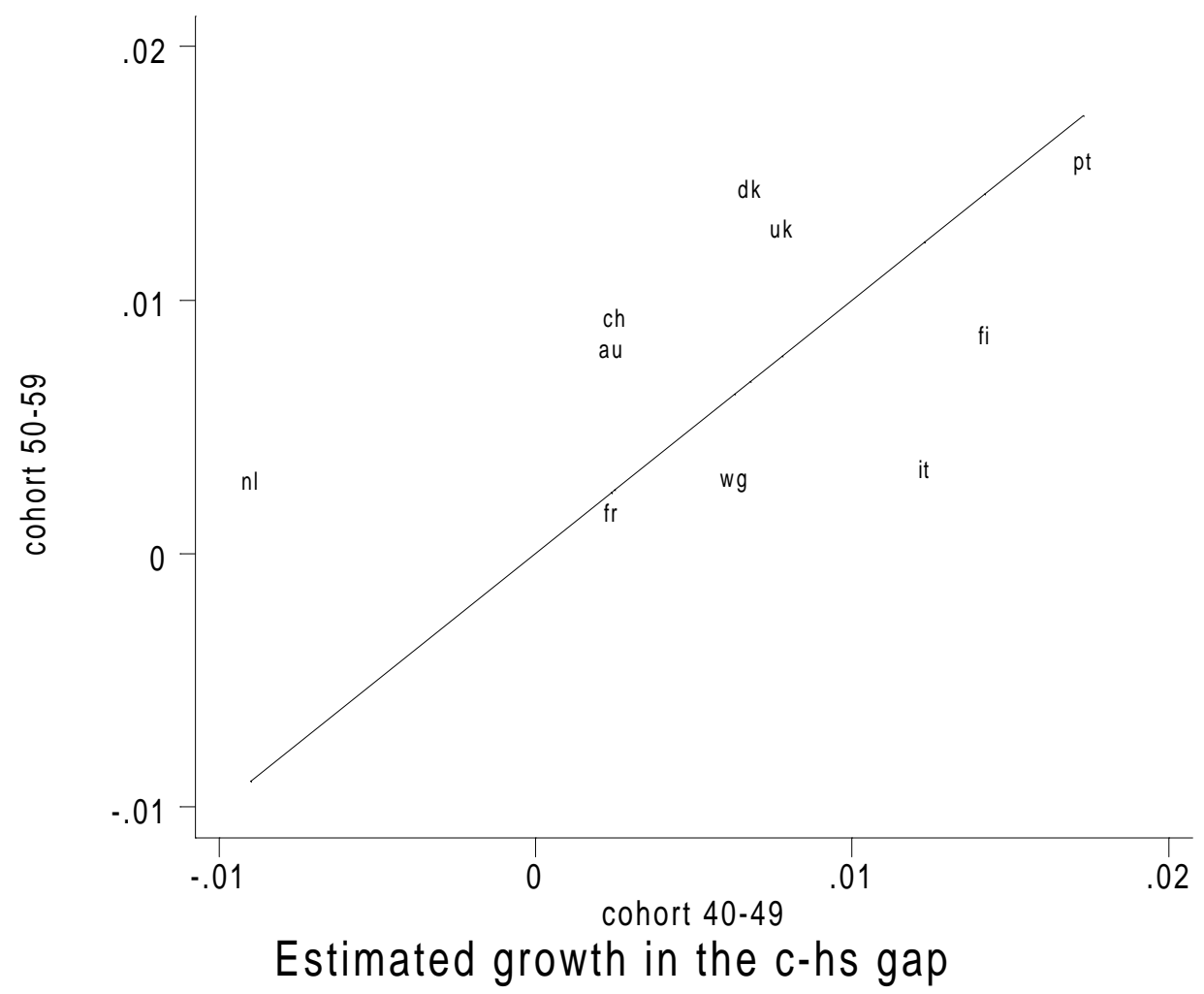

Figure 4: Estimated Growth in the Gap for the two cohorts 


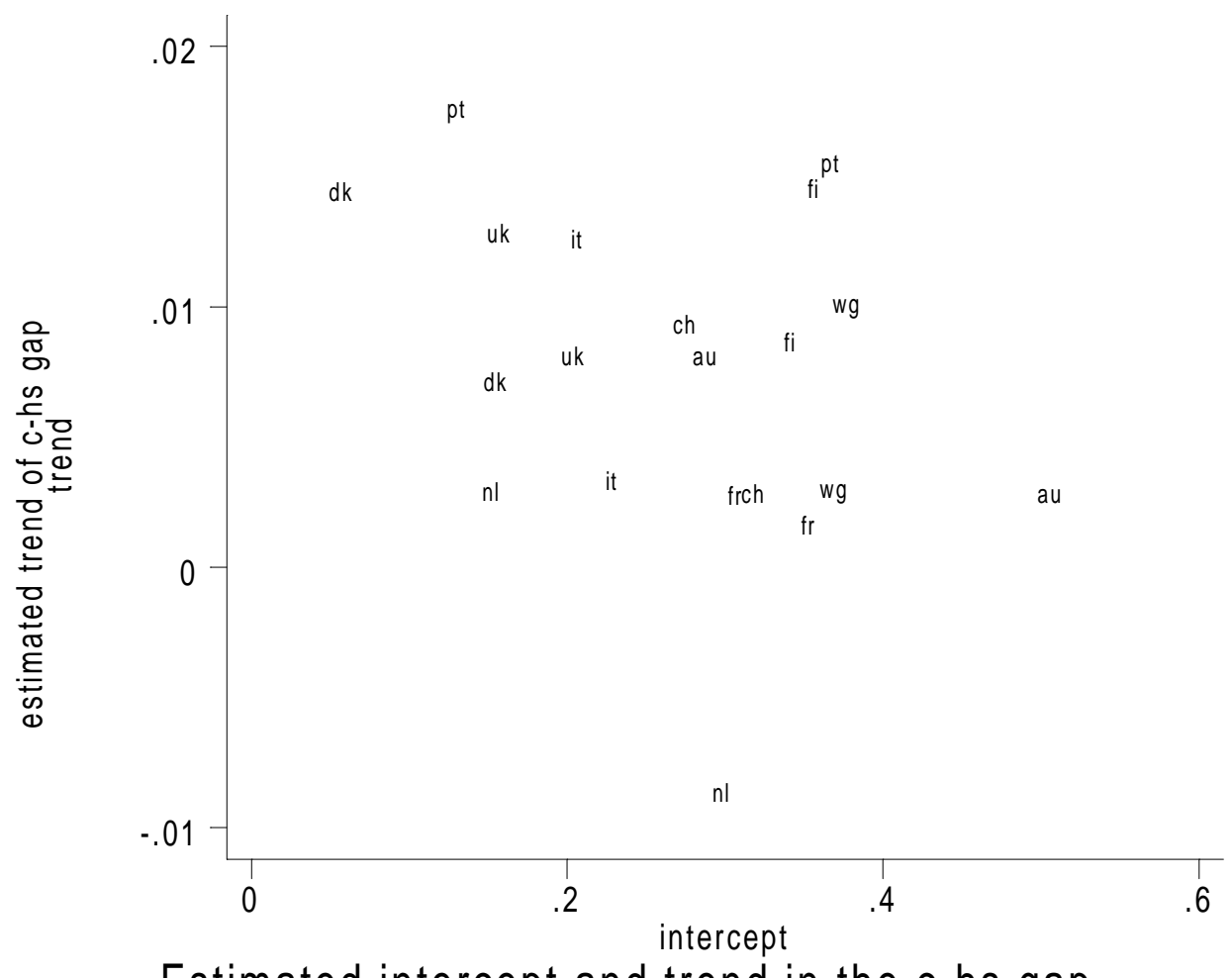

Estimated intercept and trend in the c-hs gap

Figure 5: Intercept and Slope 


\section{IZA Discussion Papers}

No Author(s)

141 R. Hujer M. Wellner

142 J. J. Dolado

F. Felgueroso

J. F. Jimeno

143 P. J. Luke

M. E. Schaffer

144 G. Saint-Paul

145 M.-S. Yun

146 T. K. Bauer

J. P. Haisken-DeNew

147 M. Belot

J. C. van Ours

148 L. Goerke

149 R. Lalive

J. C. van Ours

J. Zweimüller

150 J. DiNardo

K. F. Hallock

J.-St. Pischke

151 M. Ward

152 J. J. Dolado

F. Felgueroso

J. F. Jimeno

153 A. S. Kalwij

M. Gregory

154 M. Gerfin

M. Lechner

155 J. Hansen
Titel

Area

Date

The Effects of Public Sector Sponsored Training on Individual Employment Performance in East Germany

Explaining Youth Labor Market Problems in Spain: 3 Crowding-Out, Institutions, or Technology Shifts?

Wage Determination in Russia: An Econometric 4 Investigation

$4 / 00$

Flexibility vs. Rigidity: Does Spain have the worst of 1 both Worlds?

Decomposition Analysis for a Binary Choice Model 7

$4 / 00$

Employer Learning and the Returns to Schooling 5

$4 / 00$

$4 / 00$

Does the Recent Success of Some OECD 3

3

Countries in Lowering their Unemployment Rates

Lie in the Clever Design of their Labour Market

Reforms?

Employment Effects of Labour Taxation in an Efficiency Wage Model with Alternative Budget Constraints and Time Horizons

The Impact of Active Labor Market Programs and Benefit Entitlement Rules on the Duration of Unemployment

Unions and the Labor Market for Managers

Gender, Salary and Promotion in the Academic 5 Profession

$5 / 00$

The Role of the Minimum Wage in the Welfare 3 State: An Appraisal

$5 / 00$

Overtime Hours in Great Britain over the Period 3 1975-1999: A Panel Data Analysis

Microeconometric Evaluation of the Active Labour 6 Market Policy in Switzerland

$5 / 00$

$5 / 00$

The Duration of Immigrants' Unemployment Spells: $\quad 1 / 3$ Evidence from Sweden 


\begin{tabular}{|c|c|c|c|c|}
\hline 156 & $\begin{array}{l}\text { C. Dustmann } \\
\text { F. Fabbri }\end{array}$ & $\begin{array}{l}\text { Language Proficiency and Labour Market Per- } \\
\text { formance of Immigrants in the UK }\end{array}$ & 1 & $5 / 00$ \\
\hline 157 & $\begin{array}{l}\text { P. Apps } \\
\text { R. Rees }\end{array}$ & $\begin{array}{l}\text { Household Production, Full Consumption and } \\
\text { the Costs of Children }\end{array}$ & 7 & $5 / 00$ \\
\hline 158 & $\begin{array}{l}\text { A. Björklund } \\
\text { T. Eriksson } \\
\text { M. Jäntti } \\
\text { O. Raaum } \\
\text { E. Österbacka }\end{array}$ & $\begin{array}{l}\text { Brother Correlations in Earnings in Denmark, } \\
\text { Finland, Norway and Sweden Compared to the } \\
\text { United States }\end{array}$ & 5 & $5 / 00$ \\
\hline 159 & $\begin{array}{l}\text { P.- J. Jost } \\
\text { M. Kräkel }\end{array}$ & Preemptive Behavior in Sequential Tournaments & 5 & $5 / 00$ \\
\hline 160 & M. Lofstrom & $\begin{array}{l}\text { A Comparison of the Human Capital and Signaling } \\
\text { Models: The Case of the Self-Employed and the } \\
\text { Increase in the Schooling Premium in the 1980's }\end{array}$ & 5 & $6 / 00$ \\
\hline 161 & $\begin{array}{l}\text { V. Gimpelson } \\
\text { D. Treisman } \\
\text { G. Monusova }\end{array}$ & $\begin{array}{l}\text { Public Employment and Redistributive Politics: } \\
\text { Evidence from Russia's Regions }\end{array}$ & 4 & $6 / 00$ \\
\hline 162 & $\begin{array}{l}\text { C. Dustmann } \\
\text { M. E. Rochina- } \\
\text { Barrachina }\end{array}$ & $\begin{array}{l}\text { Selection Correction in Panel Data Models: An } \\
\text { Application to Labour Supply and Wages }\end{array}$ & 6 & $6 / 00$ \\
\hline 163 & $\begin{array}{l}\text { R. A. Hart } \\
\text { Y. Ma }\end{array}$ & Why do Firms Pay an Overtime Premium? & 5 & $6 / 00$ \\
\hline 164 & $\begin{array}{l}\text { M. A. Shields } \\
\text { S. Wheatley Price }\end{array}$ & $\begin{array}{l}\text { Racial Harassment, Job Satisfaction and Intentions } \\
\text { to Quit: Evidence from the British Nursing } \\
\text { Profession }\end{array}$ & 5 & $6 / 00$ \\
\hline 165 & P. J. Pedersen & $\begin{array}{l}\text { Immigration in a High Unemployment Economy: } \\
\text { The Recent Danish Experience }\end{array}$ & 1 & $6 / 00$ \\
\hline 166 & $\begin{array}{l}\text { Z. MacDonald } \\
\text { M. A. Shields }\end{array}$ & $\begin{array}{l}\text { The Impact of Alcohol Consumption on Occupa- } \\
\text { tional Attainment in England }\end{array}$ & 5 & $6 / 00$ \\
\hline 167 & $\begin{array}{l}\text { A. Barrett } \\
\text { J. FitzGerald } \\
\text { B. Nolan }\end{array}$ & $\begin{array}{l}\text { Earnings Inequality, Returns to Education and } \\
\text { Immigration into Ireland }\end{array}$ & 5 & $6 / 00$ \\
\hline 168 & $\begin{array}{l}\text { G. S. Epstein } \\
\text { A. L. Hillman }\end{array}$ & $\begin{array}{l}\text { Social Harmony at the Boundaries of the Welfare } \\
\text { State: Immigrants and Social Transfers }\end{array}$ & 3 & $6 / 00$ \\
\hline 169 & R. Winkelmann & $\begin{array}{l}\text { Immigration Policies and their Impact: The Case of } \\
\text { New Zealand and Australia }\end{array}$ & 1 & $7 / 00$ \\
\hline 170 & $\begin{array}{l}\text { T. K. Bauer } \\
\text { K. F. Zimmermann }\end{array}$ & $\begin{array}{l}\text { Immigration Policy in Integrated National } \\
\text { Economies }\end{array}$ & 1 & $7 / 00$ \\
\hline 171 & $\begin{array}{l}\text { C. Dustmann } \\
\text { F. Windmeijer }\end{array}$ & $\begin{array}{l}\text { Wages and the Demand for Health - A Life Cycle } \\
\text { Analysis }\end{array}$ & 5 & $7 / 00$ \\
\hline 172 & D. Card & $\begin{array}{l}\text { Reforming the Financial Incentives of the Welfare } \\
\text { System }\end{array}$ & 3 & $7 / 00$ \\
\hline 173 & D. S. Hamermesh & Timing, Togetherness and Time Windfalls & 5 & $7 / 00$ \\
\hline
\end{tabular}



M. Ward

180 T. K. Bauer I. N. Gang

E. Wasmer

Y. Zenou

184 M. Corak

B. Gustafsson

T. Österberg

185 H. Bonin

K. F. Zimmermann

A. S. Kalwij

A. Zaidi 
223 M. Rosholm

Wages, Training, and Job Turnover in a Search-

1 former Soviet Union to Israel: Who is coming when?

S. Comi Countries: Evidence from Two Cohorts 